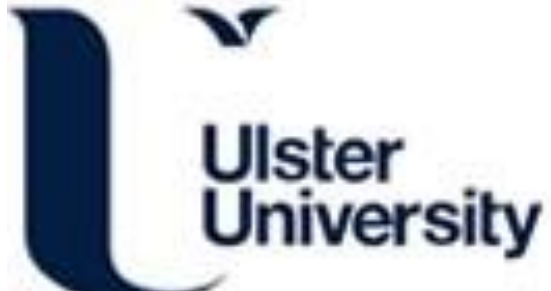

Biomass Gasification for Combined Heat and Power in the Chipboard Industry

Williams, BC., Henderson, P., \& Mcllveen-Wright, D. (2003). Biomass Gasification for Combined Heat and Power in the Chipboard Industry. Developments in Chemical Engineering and Mineral Processing, 11(1-2), 7993. https://doi.org/10.1002/apj.5500110208

Link to publication record in Ulster University Research Portal

\section{Published in:}

Developments in Chemical Engineering and Mineral Processing

Publication Status:

Published (in print/issue): 01/01/2003

DOI:

10.1002/apj.5500110208

\section{Document Version}

Author Accepted version

\section{General rights}

Copyright for the publications made accessible via Ulster University's Research Portal is retained by the author(s) and / or other copyright owners and it is a condition of accessing these publications that users recognise and abide by the legal requirements associated with these rights.

\section{Take down policy}

The Research Portal is Ulster University's institutional repository that provides access to Ulster's research outputs. Every effort has been made to ensure that content in the Research Portal does not infringe any person's rights, or applicable UK laws. If you discover content in the Research Portal that you believe breaches copyright or violates any law, please contact pure-support@ulster.ac.uk. 


\title{
Biomass Gasification for Combined Heat and Power in the Chipboard Industry
}

\author{
B.C. Williams*, P. Henderson and D. McIlveen-Wright \\ NICERT, University of Ulster, Coleraine BT52 1SA, Northern Ireland, \\ $U K$
}

\begin{abstract}
This paper provides details of a feasibility study into the application of small-scale wood chip gasification-based combined heat and power (CHP). Gasification itself is not a new technology, however there has been renewed interest recently in the quest for small-scale gasification from renewable energy sources, such as biomass and wood waste. The UK Government is committed under the Kyoto Protocol and various EC regulations and recommendations to reducing greenhouse gas emissions, increasing the use of renewable energy sources and increasing energy efficiency through the use of CHP. This technology will help to achieve all three of these goals.

There has been an assessment of the wood chip supply position in Ireland, based on information from Balcas, the largest timber milling company in Ireland, and the Northern Ireland Forestry Service. This study shows that there has been a 30\% increase in output from Ireland's forests over the last five years. A conservative estimate is that over the next five years the output will increase by another 60\%, mainly in the North West of Ireland. Therefore, the volume of wood chips required for any proposed size of CHP unit is not expected to have any noticeable impact on the market price or availability of wood chips.
\end{abstract}


*Author for correspondence.

\section{Introduction}

This paper will provide details of a feasibility study into the application of small-scale biomass gasification with a gas engine as a means of providing combined heat and power (CHP) to the chipboard manufacturing industry. The feasibility study will be based on energy usage data and energy costs for a chipboard plant. The plant has a production capacity of $105,000 \mathrm{~m}^{3} /$ year of chipboard, and it operates 24 hours a day, 362 days in the year. Gasification itself is not a new technology. However, there has been renewed interest recently in the quest for small-scale gasification from renewable energy sources, such as biomass and wood waste. This technology has been demonstrated in Northern Ireland using wood chips, and indeed it is fair to say that Northern Ireland is a World leader in this technology. In addition the availability and cost of biomass suitable for use in a small-scale biomass gasification based CHP will be assessed.

CHP is the on-site generation and use of heat and electricity. In a CHP unit an engine is connected to a generator to produce electricity, while the engine jacket and exhaust heat are used to produce steam or hot water. Again, this technology is not new and CHP fired by fossil fuels, such as natural gas and diesel, is widely used across UK and Europe. The basic CHP unit consists of five components, an engine, an electrical generator, a heat recovery system, a control system and an exhaust system. CHP has many advantages to the user. Primarily there is a reduction in energy costs, a security against electricity price fluctuation and a back-up electricity supply. Additionally $\mathrm{CHP}$ can lead to significant savings in $\mathrm{CO}_{2}$ emissions and companies are interested in its use to promote good environmental and sustainable company policies.

The UK Government is committed under the Kyoto Protocol to reducing greenhouse gas emissions, increasing the use of renewable energy sources and increasing efficiency through the use of CHP. This technology helps to achieve all three of these goals. Today, with the UK Government proposal of a Climate Change Levy on fossil fuels, many companies are becoming interested in CHP as a means of reducing the impact of this new levy and off-setting the company energy bill.

\section{Availability of Biomass Feedstock}

Experience of gasifying wood chips in a gasifier at the Blackwater Valley Museum has allowed a specification for the wood chip feedstock to be obtained, as follows:

Bark content - maximum 5\%

Moisture Content - less than $50 \%$ wet basis

No contaminants 
No long sticks greater than $150 \mathrm{~mm}$

Typical size distribution:

\begin{tabular}{|l|l|}
\hline Size range & $\%$ (by weight) \\
\hline Below $5 \times 5 \mathrm{~mm}$ & $2-3$ \\
\hline $5 \times 5 \mathrm{~mm}-10 \times 10 \mathrm{~mm}$ & $6-11$ \\
\hline $10 \times 10 \mathrm{~mm}-15 \times 15 \mathrm{~mm}$ & $12-19$ \\
\hline $15 \times 15 \mathrm{~mm}-20 \times 20 \mathrm{~mm}$ & $20-24$ \\
\hline $20 \times 20 \mathrm{~mm}-25 \times 25 \mathrm{~mm}$ & $25-30$ \\
\hline $25 \times 25 \mathrm{~mm}-30 \times 30 \mathrm{~mm}$ & $9-20$ \\
\hline $30 \times 30 \mathrm{~mm}-35 \times 35 \mathrm{~mm}$ & about 5 \\
\hline $35 \times 35 \mathrm{~mm}$ and above & about 3 \\
\hline
\end{tabular}

The chipboard plant purchases approximately 140,000 tonnes per year wood for use in their production process. The majority of this is supplied as wood chips from a variety of sources, mostly wood mills. One of the first stages in the wood milling process is the removal of bark. Therefore the wood chips contain only trace amounts of bark and this will therefore satisfy the first element of the gasification specification. The wood chips as received are analysed for moisture content and the range can be between $20 \%$ and $60 \%$ on a wet basis. Payment is based on a $£ /$ wet tonne bas is and if the moisture content exceeds $50 \%$ then complaints are usually made to the supplier. However, it is realised that there is variability in the wood chip moisture content and as the chips are stored outside this will also introduce some further seasonal variability.

The size distribution of the wood chips at the chipboard plant was as sessed by the manufacturer of the gasifier as being satisfactory for their gasifier. Indeed, the plant at the Blackwater Valley Museum takes wood chips from some of the same sources as the chipboard plant. The question of preventing long sticks and contaminants from entering the gasifier is an issue that will need to be addressed at a later stage during the detailed plant design stage.

The conclusion therefore is that the normal wood chips purchased for the production process will be satisfactory for the gasifier, although the variable moisture content will affect the low grade heat available from the CHP unit.

Obviously the supply of wood chips is vital to the viability of the plant. The owners have recently made a study of the medium to long-term availability of suitable wood chips. This study assumed that the wood chips would be supplied mainly as 'sawmill residue' or as recycled material, similar to that currently used by the chipboard plant in their production process. This study was mainly based on a similar 
study undertaken by Ireland's largest sawmill company, which has facilities in Enniskillen, Magherafelt and Leitrim. Some information on wood production and replanting has been included from the Northern Ireland Forest Service Corporate and Business Plans 2000/01 - 2004/05. In addition, a brief study of future sawmill residue supply over the next three years was undertaken by Sonae UK personnel.

The key is sues highlighted by the study can be summarised as follows:

- Over the last five years, the output from Ireland's forests has increased by $30 \%$.

- By 2005 the forest output will be $30 \%$ greater than the current level of consumption.

- Usage currently is less than the potential forest output.

- Increased sawmill capacity is being installed.

- Sawmill residues by 2005 will potentially increase by $60 \%$.

- The main expansion of forestry will be in the North West of Ireland.

The following shows projected Northern Ireland Forest Service wood production and replanting 2000/2001 - 2004/2005:

\begin{tabular}{|l|c|c|c|c|c|}
\hline & $2000 / 01$ & $2001 / 02$ & $2002 / 03$ & $2003 / 04$ & $2004 / 05$ \\
\hline Timber Production $\left(\mathrm{m}^{3}\right)$ & 340,000 & 360,000 & 380,000 & 400,000 & 410,000 \\
\hline Replanting (ha) & 800 & 900 & 900 & 900 & 900 \\
\hline
\end{tabular}

These figures are thought to be conservative, and actual production in 2005 could potentially be double the current figure. Sonae have shown, from discussions with the major sawmills, that the total yearly timber used by the chipboard plant (currently 133,000 tonnes in the process and $5000-6000$ tonnes of boiler fuel) could easily be doubled in the next three years, due to sawmill expansion programmes.

The information available shows that there is currently more sawmill residue available than is being used locally, so that a considerable amount of material is exported. Also, there will be a large surplus of sawmill residue by 2003, provided that there are no new board mill projects or major expansions of existing plants (i.e. chipboard, MDF or OSB). This takes into account expansion plans of some of the major sawmills.

\section{Detailed Feasibility Study}

This section will describe:

- the methodology used to perform the study;

- the energy systems and profiles at the chipboard plant site; 
- the performance of the CHP unit;

- options for integrating the CHP unit into the chipboard plant site;

- results from the feasibility study;

- discussion of the results.

\section{Methodology}

This project has followed the guidelines set out in the Energy Efficiency Good Practice books No.1, 3 and 43. A full investigation of the energy systems in operation at the chipboard plant site was carried out. Using data that had been gathered over a threeyear period detailed electrical and thermal energy profiles and costs were generated. Information was then gathered about the operation of the biomass gasifier CHP unit. Options for integrating the electrical and heat output from the CHP unit with the site energy profiles were then explored and a decision made about the most appropriate size of CHP unit. An in-depth technical and economic analysis of these options was then performed, together with a sensitivity analysis of the important variable factors most likely to influence the results.

\section{The Chipboard Process Plant}

The basic flowsheet for the chipboard process plant is given in Figure 1. The raw material for the production line consists of tree logs, sawmill waste (chips and dust) and recycled waste wood. The wood is sourced from within Ireland, ideally as close to the factory as possible, thereby reducing transport costs. The first stage in production is to chop the larger wood sections into chips. These chips are passed through a rolling mill to remove excess moisture and then on to a hammer mill to reduce the chip size to that which is required for production. The chips are then transferred to one of two rotary dryers where the moisture is evaporated and the chips dried to typically $2 \%$ moisture content. The dryers can be fired on either heavy fuel oil (HFO) or wood dust, which is a by-product from the sanding line, depending upon availability of dust.

After drying, the product is sieved into three categories, core, fines and oversized, the first two categories are suitable for making chipboard, while the oversized chips are returned for further size reduction to make them suitable for chipboard production. The fine and core materials are metered into the blending plant where resin and other components are added. The chips are then laid out on a moving belt and carried into the heated presses. The fine and core materials are laid out in sandwich format with the fine material on both external surfaces and the core material sandwiched in the middle. In the press the board receives two to eight minutes of compression and heating depending on the board thickness and the required specification. After pressing, the boards are cooled then passed through the sanding line, which reduces them to the required thickness before sawing to specified sizes.

Energy costs in Northern Ireland have always been expensive and the chipboard plant has a long track record in reducing energy costs. As part of this programme, a data acquisition system was installed to monitor the electrical and thermal performance of the site. The data acquisition system is used to continuously monitor the electrical 
B.C. Williams, P. Henderson and D. McIlveen-Wright

consumption on the site. In part this allows production to be maintained at a maximum within the constraints of the electricity tariff structure. Using data gathered over a period of three years, an electrical profile of the production line was constructed, which provides an insight into how the plant operates. For most of the year the electrical consumption is fairly constant, except during the annual shutdowns. 


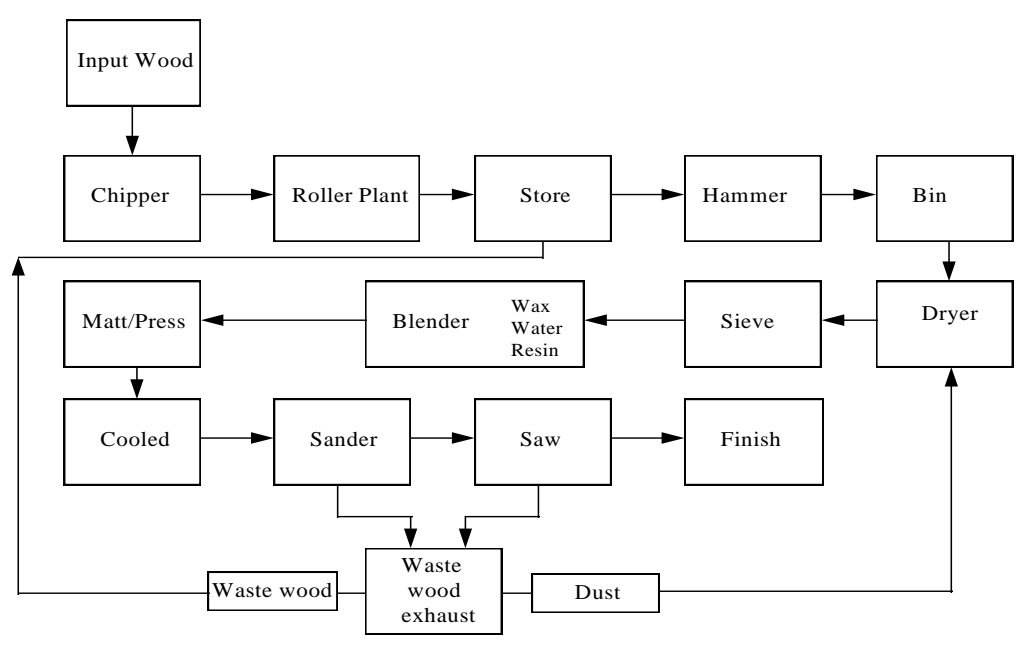

Figure 1. Basic flowsheet of the chipboard process plant.

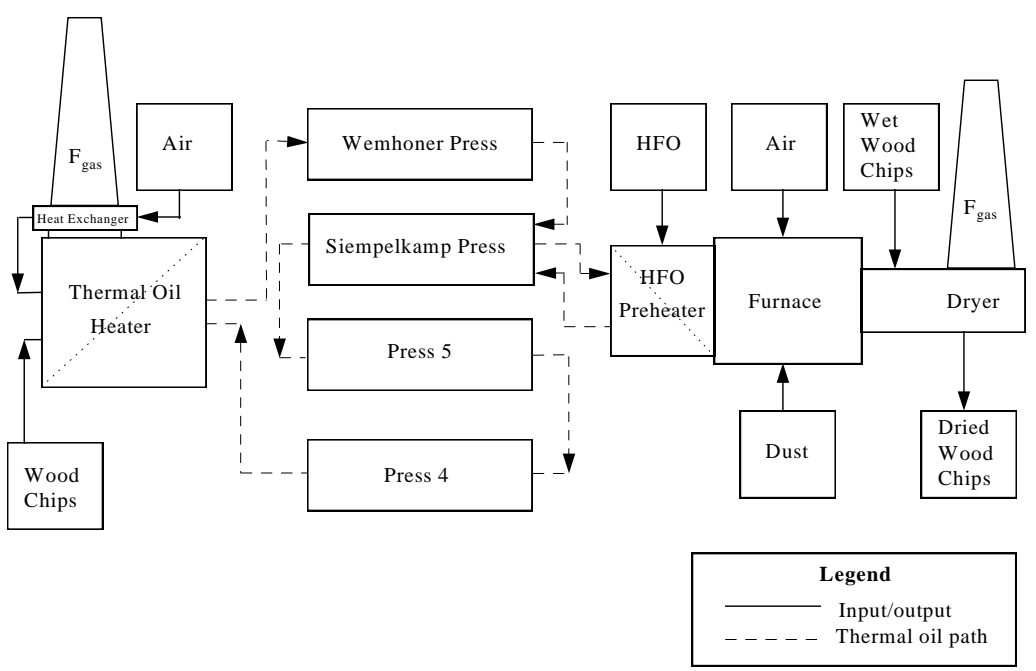

Figure 2. Chipboard process plant heating systems. 
On a daily basis the production is reduced during the period 16:30 - 19:30 to avoid the high electricity tariff period. Between 20:30 and 8:00 there is an increase in electrical usage as a result of sanding, which occurs only in the evening. If the electrical usage of the sander is removed, the site profile flattens out substantially. The time weighted average electricity purchase price at the chipboard plant is $2.8 \mathrm{p} / \mathrm{kWh}$. In addition to this cost it is expected that the Climate Change Levy will introduce an additional 0.43 $\mathrm{p} / \mathrm{kWh}$ for electricity.

Using the electricity profile data for the site an assessment can be made of the potential occupancy that a given size of CHP unit could have, assuming that it limited by the site electrical demand and that export of electricity is not considered. Table 1 shows the results for the period 1/4/1999 - 31/3/2000. From this table it has been seen that a CHP unit up to $1000 \mathrm{kWe}$ in size will have a potential occupancy approaching $100 \%$.

\begin{tabular}{|c|c|}
\hline Size $(\mathrm{kW})$ & Occupancy $(\%)$ \\
\hline 200 & 99 \\
\hline 1000 & 99 \\
\hline 1500 & 76 \\
\hline 2000 & 65 \\
\hline
\end{tabular}

Table 1. Potential CHP occupancy.

Within the chipboard plant site, two heating systems are present as illustrated in Figure 2, namely a thermal oil heater and a furnace to provide hot air to the dryers. On the factory production line, a constant heat source is required for the presses to ensure quality of production. This is achieved by heating thermal oil and circulating this to the four main presses on the site. There is also a small demand for thermal oil to preheat the HFO. This is necessary to reduce the viscosity of the HFO to enable it to burn efficiently. As a backup to the thermal oil, electric heaters may be used for HFO preheating.

A heat profile for the thermal oil usage was generated using data recorded on the site and design data. Table 2 shows the temperature differences and flow rates of the thermal oil round the system. From these it can be shown that the boiler output is approximately $3200 \mathrm{~kW}$ th, with a temperature difference between input and output streams of approximately $40^{\circ} \mathrm{C}$. This temperature difference remains constant during the 24-hour period, except for slight variations as a result of opening and closing the presses.

\begin{tabular}{|l|c|c|c|c|c|}
\hline & Temp. ${ }^{\circ} \mathrm{C}$ & Flow $\mathrm{kg} / \mathrm{s}$ & Tdiff ${ }^{\circ} \mathrm{C}$ & $\begin{array}{c}C p \\
k J / k g K\end{array}$ & Heat $k$ Wth \\
\hline Line IV & 255 & 13 & 35 & 2.67 & 1230 \\
\hline Line V & 255 & 14 & 35 & 2.67 & 1302 \\
\hline Wemhoner & 200 & 4 & 30 & 2.49 & 288 \\
\hline Siemplekemp & 210 & 4 & 30 & 2.59 & 299 \\
\hline
\end{tabular}




\begin{tabular}{|l|l|l|l|l|l|}
\hline Preheat HFO & 177 & 1 & 40 & 2.41 & 114 \\
\hline
\end{tabular}

\section{Table 2. Thermal oil data.}

The thermal oil is heated using a wood-burning incinerator. The wood is purchased by weight, as determined by the weighbridge at the entrance to the plant. The moisture content will vary between $20 \%$ and $60 \%$ on a wet basis due to supplier differences, seasonal changes and the introduction of dry factory waste. Table 3 illustrates how much wood is used per day.

\begin{tabular}{|c|c|c|c|c|}
\hline Type of Wood & Total for 1999 & Average Daily & Estimated Avg & Cost/Day \\
\hline & (tonnes) & (tonnes) & Cost/tonne & $(£)$ \\
\hline Dry Waste & 238 & 0.67 & 0.00 & 0.00 \\
\hline Peelings & 3966 & 11.11 & 12.22 & 135.75 \\
\hline Chips & 498 & 1.39 & 13.75 & 19.18 \\
\hline Waste Wood & 804 & 2.25 & 14.25 & 32.10 \\
\hline Totals & 5506 & 15.42 & & 187.03 \\
\hline
\end{tabular}

Table 3. Wood used on thermal oil heater.

The dryers are an essential part of the production process, as they dry the wood chips before they are used to make chipboard. The wood chips are dried in one of two rotary driers in a stream of hot air. The air is heated by direct combustion of either waste wood dust, if it is available, or HFO. System data for the dryer is shown in Table 4. The table shows that the design capacity is $10 \mathrm{MWth}$, but from investigation, the normal operating load is about $8.6 \mathrm{MW}$ th.

\begin{tabular}{|l|l|c|}
\hline \multicolumn{1}{|c|}{ Dryer Part } & \multicolumn{1}{|c|}{ Description } & Value (maximum) \\
\hline Dryer performance & Throughput of wood & $8160 \mathrm{~kg} / \mathrm{h}$ \\
\hline & Water evaporation & $13000 \mathrm{~kg} / \mathrm{h}$ \\
\hline & Heat requirement & $8.6 \mathrm{MWth}$ \\
\hline Burner rating & Capacity & $10.0 \mathrm{MWth}$ \\
\hline
\end{tabular}

Table 4. Wood chip dryer capacities.

The records at the chipboard plant show that approximately 80,000 litres per week of HFO are used in the dryers. Due to the limited storage facilities for the dust, it must 
be used at the same time as it is produced. Therefore, between 00:00 and 11:30, when dust is available from the sanding operation, the dryers will operate using the generated dust, with approximately $50 \mathrm{~kg} / \mathrm{h}$ of HFO as a pilot light to aid combustion of the dust. Outside of this time the dryer will operate using only HFO. The HFO usages for 1998/1999 are shown in Table 5.

\begin{tabular}{|l|c|c|c|c|}
\hline & 1999 & & 1998 & \\
\hline Month & Dryer $1(\mathrm{~kg})$ & Dryer 2 $(\mathrm{kg})$ & Dryer 1 $(\mathrm{kg})$ & Dryer 2 $(\mathrm{kg})$ \\
\hline January & 260000 & 266794 & 202852 & 294082 \\
\hline February & 200000 & 202507 & 192289 & 216724 \\
\hline March & 220000 & 226379 & 238474 & 224534 \\
\hline April & 200000 & 199216 & 197401 & 186102 \\
\hline May & 166550 & 172547 & 215224 & 148424 \\
\hline June & 159976 & 148464 & 192236 & 143122 \\
\hline July & 149008 & 149319 & 219255 & 171416 \\
\hline August & 147355 & 178023 & 229052 & 205556 \\
\hline September & 129115 & 99949 & 120000 & 118316 \\
\hline October & 184920 & 166049 & 246364 & 206816 \\
\hline November & 164938 & 207559 & 209233 & 269378 \\
\hline December & 213751 & 211875 & 186531 & 257158 \\
\hline Subtotal & 2195613 & 2228681 & 2448911 & 2441628 \\
\hline Total/year & 4424294 & & 4890539 & \\
\hline
\end{tabular}

Table 5. Heavy fuel oil usages.

\section{The CHP Unit}

As mentioned previously, CHP is the on-site generation and use of heat and electricity. In a CHP unit a turbine or engine is connected to a generator to produce electricity, while the engine jacket and exhaust heat is used to produce steam or hot water. The standard CHP technology uses fossil fuels, typically natural gas or diesel oil, to fire the turbine or engine. What is new about this technology is that the engine is fired on syngas produced by the gasification of biomass wood chips.

Biomass gasification is not a new process, indeed it is nearly 200 years since wood gas was first used to produce power. However, it was in Scandinavia during the first half of the last century that most of the development work was performed on a biomass gasifier system used to generate fuel gas to drive an engine. This technology was used extensively during World War II when imported liquid transport fuels were not available. After the war the development was stopped due the renewed supply of cheap oil, but during the oil cris is of the 1970's, further research occurred.

Gasification is the process of converting the carbon and hydrogen in the original feedstock into a gaseous mixture of mainly $\mathrm{CH}_{4}, \mathrm{CO}$ and $\mathrm{H}_{2}$. This process takes place when wood is heated with some oxygen or air, but with not enough oxygen for complete combustion to $\mathrm{CO}_{2}$ and water. This partial oxidation at elevated temperatures occurs at between $900^{\circ} \mathrm{C}$ and $1100^{\circ} \mathrm{C}$ with air and between $1100^{\circ} \mathrm{C}$ and $1400^{\circ} \mathrm{C}$ with 
oxygen. For small-scale gasification, i.e. below $5 \mathrm{MW}$, there are two widely used technologies, up-draft and down-draft gasification. As the two names suggest, the up-draft system is countercurrent while the down-draft is co-current. The countercurrent system has the advantage of higher thermal efficiency, but can cause tars and oils to be carried over producing a dirty fuel gas. This problem is significantly reduced by using a co-current gasifier.

The co-current system has several distinct zones for drying, devolatisation, combustion and gasification. The downdraft gasifier can be considered a wellinsulated, vertical, hollow cylinder with a restriction (the throat) about two-thirds of the distance down from the top. A grid or hearth, which supports and contains the wood, is situated below the throat. Fuel is fed continuously from the top and the fuel gas is drawn from the bottom of the system below the hearth by the engine. The air for the gasification reactions is blown or sucked into the gasifier via a pipe with inlets near the throat. Near the air inlets exothermal partial combustion takes place, causing a char bed to form below the air inlets.

Beyond the combustion zone, gasification takes place. The heat produced in the combustion zone will dry the incoming wood and help to drive the endothermic gasification reactions. The more heat that is available for the gasification reactions, then the greater the production of fuel gas. Therefore it is necessary to miminise the moisture level of the incoming wood. The reduction in tar is possible due to the oxidation of the pyrolysis gas. The wood starts to pyrolysis in the upper section and the pyrolysis gas is mixed with the combustion gas. Pyrolysis gas will contain heavy tar forming components, but as result of the mixing, the gas is oxidised, producing a clean gas output.

Between the gasifier and the engine, the fuel gas is further cleaned to protect the engine. The gas is cleaned to remove any tars and cooled in a condenser before being piped to the engine of the CHP plant. Then, via an alternator, electricity is generated at $415 \mathrm{~V}$ and may be transformed up to $11 \mathrm{kV}$ if required. Heat is recovered from the engine jacket and the exhaust.

The preliminary design for a CHP unit envisages that the wood chips will be delivered by lorry six times per week and unloaded directly into an enclosed wood chip storage area. The installation comprises a number of $200 \mathrm{kWe}$ units operating in parallel. Wood chips are fed automatically from the storage area into the drier. The drier uses waste heat from the engine to dry the wood chips and then it feeds them into the gasifier. The gas is then cleaned, cooled, mixed with air and fed into the engine.

The engine is a spark ignition internal combustion engine. The gas air mixture enters the cylinders, is compressed, and ignited by spark plugs. This internal combustion rotates the engine shaft, which, as it is coupled to a generator, produces electricity. The dimension of each gasification unit is approximately $2 \mathrm{~m}$ by $4 \mathrm{~m}$ and the engine size is similar to a truck engine. The engine exhaust contains a considerable amount of heat. This heat is recovered by diverting the exhaust through a heat exchanger. Heat is also recovered from the engine radiator (cooling system) for the purpose of drying the wood chips. Each unit will produce approximately $200 \mathrm{~kW}$ of electricity and about $400 \mathrm{~kW}$ of heat. The unit starts up, shuts down and automatically 
controls within strict operating parameters. A programmable logic controller (PLC) carries out this control function.

The proposed plant will operate on a continuous basis and will comprise:

- a fuel store;

- an adjoining covered and fenced compound housing all of the small scale wood fuelled units;

- an acoustic room for the engine and generator;

- an adjoining concrete apron for delivery vehicles;

- associated electrical equipment to enable connection to the adjacent electricity supply.

The expected performance and costs of two units sized at $200 \mathrm{kWe}$ and $1000 \mathrm{kWe}$ are given in Table 6.

\begin{tabular}{|c|c|c|}
\hline & $200 \mathrm{kWe}$ & $1000 \mathrm{kWe}$ \\
\hline Electrical output (kWe) & 200 & 1000 \\
\hline Heat output (kWth) high grade & 200 & 1000 \\
\hline Heat output (kWth) low grade & 200 & 1000 \\
\hline $\begin{array}{l}\text { Wood consumption } \\
(12.5 \% \text { mois ture } \mathrm{kg} / \mathrm{h})\end{array}$ & 183 & 915 \\
\hline Aqueous waste $(1 / \mathrm{h})$ & 0 & 0 \\
\hline Tars waste $(1 / h)$ & 0 & 0 \\
\hline Engine lubricating oil $(\mathrm{g} / \mathrm{kWh})$ & 0.4 & 0.4 \\
\hline Solid waste (charcoal ash) $(\mathrm{kg} / \mathrm{h})$ & 14 & 70 \\
\hline Size of plant (m) & $\begin{array}{l}15 \times 7 \text { plus lorry } \\
\text { access }\end{array}$ & $\begin{array}{c}17 \times 17.5 \text { plus lorry } \\
\text { access }\end{array}$ \\
\hline Noise (dBA) & 75 & 75 \\
\hline Overall efficiency & 75 & 75 \\
\hline 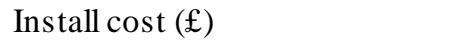 & 250,000 & $1,000,000$ \\
\hline Operating/maintenance cost $(£)$ & 25,000 & 72,600 \\
\hline Plant classification & Engine-based CHP & Engine-based CHP \\
\hline
\end{tabular}

Table 6. Performance of CHP units. 
Biomass Gasification for CHP in the Chipboard Industry

\section{CHP Options Studied}

The electricity profiles that have been presented for the factory show that up to approximately $1000 \mathrm{~kW}$ of electricity could be generated by a CHP unit operating at very high occupancy before a market for the surplus electricity has to be found. In fact the limit on the occupancy is the availability of the CHP unit and not the demand from the factory. It has also been shown that within the factory there is a demand for heat in two areas, the first is for heating the thermal oil which is mainly used in the chipboard presses, and the second is for drying the wood chips which then go to make the chipboard. This therefore presents two options for utilising the heat from a CHP unit, heating thermal oil and drying wood chips.

The existing thermal oil heating plant uses the energy from the combustion of wood to heat thermal oil from a temperature of approximately $215^{\circ} \mathrm{C}$ to $255^{\circ} \mathrm{C}$. The combustion unit is rated at $3.5 \mathrm{MW}$ th, although the thermal oil system probably requires about $3.2 \mathrm{MW}$ th. The gasifier CHP unit produces approximately $1 \mathrm{~kW}$ of lowgrade heat and $1 \mathrm{~kW}$ of high-grade heat for every $1 \mathrm{~kW}$ of electricity generated. The low-grade heat is available at a maximum temperature of $80^{\circ} \mathrm{C}$ and is therefore not suitable for heating the thermal fluid. This low-grade heat can be used for drying the wood before it enters the gasifier, but there will be a surplus of low-grade heat which must be dumped. The high-grade heat is available at a maximum temperature of $500^{\circ} \mathrm{C}$ and is therefore suitable for heating the thermal fluid. With this option two sizes of unit will be evaluated, $200 \mathrm{kWe}$ and $1000 \mathrm{kWe}$, with the high grade heat produced going through a finned tube heat exchanger to preheat the thermal oil and reduce the quantity of wood burnt in the normal thermal oil heating plant.

One important variable within the chipboard plant is the moisture content of the wood feedstock. Although the plant has one main supplier of wood chips a number of other suppliers are used that can cause variability. Additionally the wood chips are stored in the open and therefore there can be a seasonal variability in moisture content. With this option however, surplus low-grade heat is available for drying the wood to the gasifier and therefore this variability is not considered to have a significant effect on the overall economics. However, the economics of this option are sensitive to the relative energy price of the wood feedstock compared to electricity and therefore the effect of wood feedstock price on the economics will be evaluated.

With the second option the wood chips are presently dried in rotary driers using directly heated air. The first choice fuel for heating of the drier air is wood dust produced by the sanding machines. However, there is insufficient wood dust for this duty and therefore additional heat is provided by burning HFO. The air enters the heater at ambient temperature and the direct heating by either wood dust or HFO raises the temperature to $450^{\circ} \mathrm{C}$. There is the possibility of using both the low grade and high-grade heat from the CHP unit for this duty. To reduce the capital costs involved the hot exhaust gas from the engine, which provides the high-grade heat, could be piped directly into the rotary dryer without using an air-to-air heat exchanger. The low-grade heat from the engine cooling system, which is not used for drying the wood for the gasifier, could be used to preheat the dryer inlet air in a fined tube heat 
exchanger. As with option 1, two sizes of CHP unit will be evaluated, $200 \mathrm{kWe}$ and $1000 \mathrm{kWe}$, with the surplus low grade heat and all the high-grade heat produced reducing the quantity of HFO burnt in the normal heaters.

As mentioned in the first option, variability in the moisture content of the wood feedstock is a reality. Although this was not thought to have a significant impact on the economics of the first option, this is not the case here where all of the surplus lowgrade heat as well as the high-grade heat is used to replace HFO in the wood dryer. Therefore additional cases within this option will examine the effect of variability in wood moisture content. The economics of this option are also sensitive to the relative energy price of the wood feedstock compared to electricity and HFO, and therefore further cases within this option will examine the effect of wood feedstock price on the economics.

\section{Results and Discussion}

The details of the results will not be presented here, only the main findings. With the first option of heating thermal oil, none of the cases studied produce a satisfactory return on investment. Even with zero wood cost the payback period is still marginal at about six years. Larger CHP units would improve the economics from both the capital investment and the O\&M cost point of view. However, significant size increases would either reduce the occupancy of the system or require electricity to be exported. Both of these would have an adverse effect on the economics, unless a premium was available for the export of electricity from renewable energy sources, as is being proposed under the Government's Renewable Orders.

With the present energy price structure it is difficult to see this option being economic without significant capital grants. With the most attractive case, a capital grant of about $£ 500,000$ (equivalent to $50 \%$ of the total capital expenditure) would be required to make this case feasible to the chipboard plant management. To improve the economics more contribution is required from the heat produced from the CHP unit. With this option only the high-grade heat from the CHP unit can be utilised to replace heat from wood combustion. With the second option both high grade and low-grade heat can be used to replace heat from HFO combustion.

For the second option, drying the wood chips, the results show that to achieve a four year payback on this type of CHP unit a margin for repayment of capital of about $3.9 \mathrm{p} / \mathrm{kWh}$ is required for the $200 \mathrm{kWe}$ unit and about $3.2 \mathrm{p} / \mathrm{kWh}$ for the $1000 \mathrm{kWe}$ unit. With the existing wood cost, wood moisture content and electricity tariff structure at the plant, the large sized CHP unit gives less than $2.1 \mathrm{p} / \mathrm{kWh}$ and the small sized CHP unit gives about $1.4 \mathrm{p} / \mathrm{kWh}$.

The chipboard plant management would not normally consider projects with a payback period of greater than five years and most of their previous projects have realised payback periods of three to five years. For this type of project they feel that a four-year payback would be required to make the project attractive. A four-year payback for the large CHP unit is possible when either:

- There is a 55\% reduction in the cost of wood compared with present day figures to $£ 11 / \mathrm{t}$ dry basis.

- The average electricity price increases by $34 \%$ to $4.3 \mathrm{p} / \mathrm{kWh}$. 
- A capital grant of $£ 340,000$ (equivalent to $34 \%$ of the total capital investment) is available.

A four-year payback for the small CHP unit is possible when either:

- Waste wood with a gate fee of greater than $£ 7 /$ tonne dry basis is used.

- The average electricity price increases by $77 \%$ to $5.7 \mathrm{p} / \mathrm{kWh}$.

- A capital grant of $£ 160,000$ (equivalent to $65 \%$ of the total capital investment) is available.

The availability of a lower moisture content wood feedstock will certainly improve the economics of all of these options, provided this can be achieved without using additional energy or capital investment, i.e. by channeling dry waste wood chip or chipboard off-cuts from the production line to the CHP unit.

With regard to the reduction in greenhouse gas emissions with this option, electricity from the grid is replaced by electricity generated from a renewable energy source. In addition, the usage of $\mathrm{HFO}$ is reduced. Therefore, the $\mathrm{CO}_{2}$ emissions reduction for this option with the $50 \%$ moisture content wood chips is equivalent to $1820 \mathrm{t} / \mathrm{a}$ for the $200 \mathrm{kWe}$ unit and $9090 \mathrm{t} / \mathrm{a}$ for the $1000 \mathrm{kWe}$ unit, and with the $12.5 \%$ moisture content wood chips is equivalent to $2030 \mathrm{t} / \mathrm{a}$ for the $200 \mathrm{kWe}$ unit and 10,140 $\mathrm{t} / \mathrm{a}$ for the $1000 \mathrm{kWe}$ unit.

\section{Conclusions}

From this study the following conclusions can be drawn:

- The type of wood chip currently purchased by the chipboard plant for use in their production process has already been demonstrated as being suitable for use in the gasification unit.

- Information from the largest timber milling company in Ireland, and the Northern Ireland Forestry Service shows that there has been a $30 \%$ increase in output from Ireland's forests over the last five years. A conservative estimate is that over the next five years the output will increase by another $60 \%$, mainly in the North West of Ireland. Therefore, the volume of additional wood chips required for any proposed size of wood chip fired CHP unit is not expected to have any noticeable impact on the market price or availability of wood chips.

- The electricity profiles generated over a two-year period show that a CHP unit of up to $1000 \mathrm{kWe}$ could have a potential occupancy of about $99 \%$. The actual occupancy will be determined by the availability of the CHP unit, not the demand of the plant.

- There are two heating systems in use at the chipboard plant site that could utilise the heat from a CHP unit. The first system presently burns wood chips to heat thermal oil and the second system uses waste wood dust and HFO to heat air for the wood chip dryers.

- For the thermal oil system none of the CHP cases studied produce a satisfactory return on investment. Even with the $1000 \mathrm{kWe}$ unit and zero wood chip cost the 
simple payback period is marginal at about six years. With the present electricity tariff structure it is difficult to see this option being economic.

- For the wood chip dryer CHP option to achieve a pay back period of less than four years a margin for repayment of capital of about $3.9 \mathrm{p} / \mathrm{kWh}$ is required for the $200 \mathrm{kWe}$ unit and about $3.2 \mathrm{p} / \mathrm{kWh}$ for the $1000 \mathrm{kWe}$ unit. With the existing wood cost, wood moisture content and electricity tariff structure at the chipboard plant, the largest CHP unit gives a margin of less than $2.1 \mathrm{p} / \mathrm{kWh}$ and the small sized unit gives about $1.4 \mathrm{p} / \mathrm{kWh}$.

- A four-year pay back for the large CHP unit is possible if:

- There is a 55\% reduction in the cost of wood.

- The average electricity price increases by $34 \%$ to $4.3 \mathrm{p} / \mathrm{kWh}$.

- A grant of $£ 340,000$ (34\% of the capital investment) is available.

- A four-year pay back is possible for the small CHP unit if:

- Waste wood is used with a gate fee of greater than $£ 7 /$ tonne dry basis.

- The average electricity price increases by $78 \%$ to $5.7 \mathrm{p} / \mathrm{kWh}$.

- A grant of $£ 160,000$ (77\% of the capital investment) is available.

- A lower moisture content wood feedstock will certainly improve the economics of the wood chip dryer CHP options, provided this can be achieved without using additional energy or capital investment, i.e. by channeling dry waste chipboard or chipboard off-cuts from the production line to the CHP unit.

- With this option not only is there a reduction in the use of electricity generated from fossil fuels but there is also a reduction in HFO usage. Therefore, the $\mathrm{CO}_{2}$ emissions reduction for this option is equivalent to between 1820 and 2030 t/a for the $200 \mathrm{kWe}$ unit and between 9090 and 10,140 t/a for the $1000 \mathrm{kWe}$ unit, depending on the wood chip moisture content.

\section{Acknowledgements}

We would like to thank the DTI New and Renewable Energy Programme for their support of this project. We would also like to thank ETSU and their programme manager, Mr. Fred Dumbleton, for his invaluable assistance and the other partners, Spanboard Products Ltd and B9 Energy Biomass Ltd for their help and support with this project. 
Biomass Gasification for CHP in the Chipboard Industry 
B.C. Williams, P. Henderson and D. McIlveen-Wright

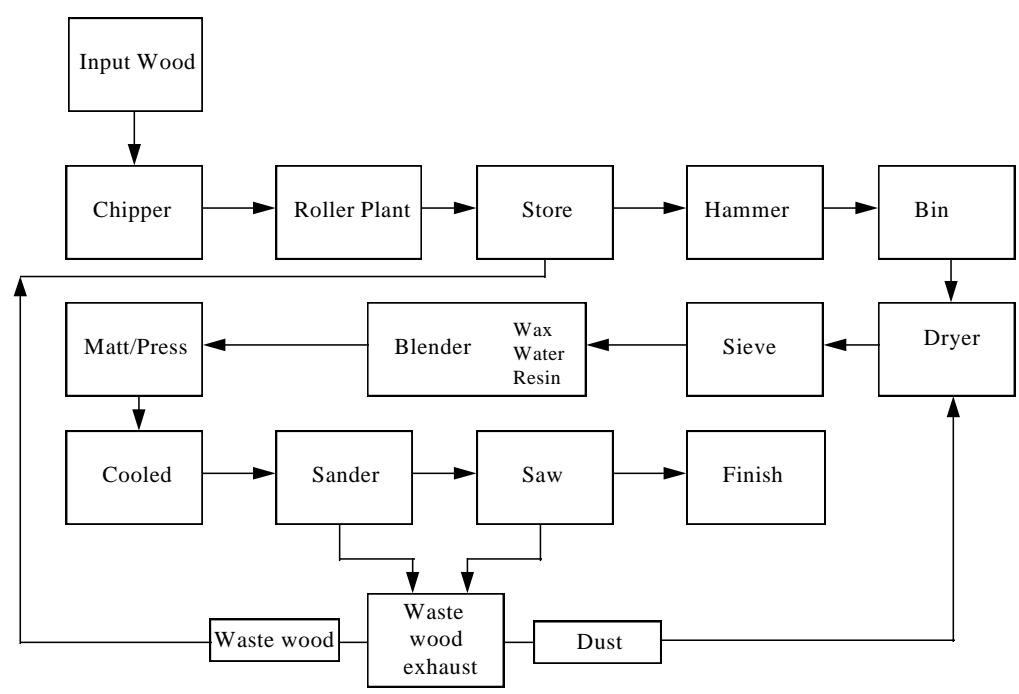

Figure 1. Basic flowsheet of the chipboard process plant.

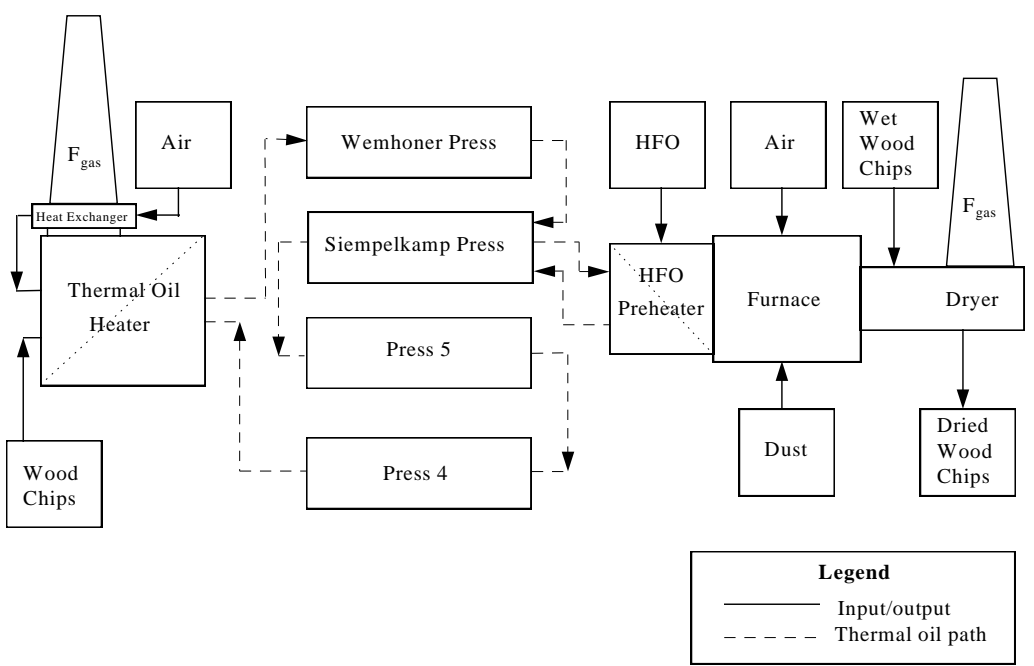

Figure 2. Chipboard process plant heating systems. 